ISSN 1428-278X | DOI: 10.18276/er.2018.35-02 | klasyfikacja JEL: 015

\title{
Mateusz DZIECHCIARZ
}

Uniwersytet Szczeciński

doktorant na Wydziale Zarządzania i Ekonomiki Usług Uniwersytetu Szczecińskiego

e-mail: mateusz.dziechciarz@gmail.com

\section{ZASTOSOWANIE ELEKTRONICZNEGO LISTU PRZEWOZOWEGO (E-CMR)}

Słowa kluczowe: transport samochodowy, międzynarodowy list przewozowy CMR, elektroniczny list przewozowy (e-CMR)

Abstrakt. Sporządzona w Genewie w 1956 roku konwencja CMR stanowi podstawę regulującą przewóz ładunków w transporcie samochodowym. Sygnatariuszami konwencji są 55 państwa europejskie oraz z kontynentów sąsiednich.

Międzynarodowy list przewozowy CMR stanowi najważniejszy dokument w transporcie samochodowym. Jest wystawiany w trzech jednobrzmiących egzemplarzach i dowolnej liczbie kopii oraz stanowi potwierdzenie przyjęcia i dostawy ładunku. Ma formę papierową z wykorzystaniem wzoru opracowanego przez Międzynarodową Unię Transportu Drogowego (IRU). List przewozowy spełnia funkcje: informacyjną, instrukcyjną, legitymacyjną i dowodową.

Zapoczątkowana w drugiej dekadzie XXI wieku czwarta rewolucja przemysłowa (Gospodarka 4.0) to trwająca do dziś intensywna cyfryzacja gospodarki. Globalne zmiany nie pozostały bez wpływu na branżę TSL. Uczestnicy łańcucha dostaw od lat mają dostęp do inteligentnych systemów śledzenia przesyłki w czasie rzeczywistym, możliwość składania zamówienia na kontenery i miejsce na statku poprzez internetowe serwisy armatorskie czy wystawiania elektronicznych dokumentów przewozowych.

Podstawą do rozpoczęcia prac nad elektronicznym listem przewozowym e-CMR był protokół dodatkowy do konwencji CMR, dotyczący elektronicznego listu przewozowego z 20 lutego 2008 roku. Pierwszy transport z wykorzystaniem listu e-CMR odbył się 19 stycznia 2017 roku pomiędzy hiszpańską Huelvą a francuskim miastem Perpignan. Do obsługi pierwszego transportu z wykorzystaniem listu e-CMR posłużyła aplikacja TransFollow. Do najważniejszych korzyści płynących z wdrożenia elektronicznego listu przewozowego e-CMR można zaliczyć: około 3-4-krotne obniżenie kosztów manipulacyjnych oraz przejrzystość i identyfikacja procesów transportowych.

Celem artykułu jest przedstawienie zagadnień związanych z konwencją CMR i międzynarodowym listem przewozowym CMR oraz prac nad rozwojem elektronicznego listu przewozowego (e-CMR). W pierwszej części artykułu scharakteryzowano konwencję CMR oraz zasady obrotu listem CMR. W drugiej części podjęto tematykę czwartej rewolucji przemy- 
słowej oraz prac związanych z wdrożeniem elektronicznego listu przewozowego e-CMR. Do przygotowania artykułu posłużyła literatura dotycząca tematyki konwencji i listu przewozowego CMR oraz źródła internetowe opisujące prace nad elektronicznym listem przewozowym e-CMR.

\section{The use of electronic consigment note e-CMR}

Keywords: road transport, international consignment note CMR, electronic consignment note e-CMR

Abtract. The CMR Convention, drawn up in Geneva in 1956, provides the basis for regulating the carriage of cargo in road transport. Signatories of the Convention are 55 countries from and outside of Europe. The CMR international consignment note is the most important document road transport. The CMR letter is issued in three identical copies and any number of copies and constitutes a confirmation of receipt and delivery of the cargo. The CMR letter is issued in paper form using a design developed by the International Union of Road Transport (IRU). The consignment note fulfils the following functions: information, instruction, identify and confirmation.

The Fourth industrial revolution, initiated in the second decade of the 21st century (Industry 4.0), is the time of intensive digitization of the economy, which is still going till nowadays. Global changes have had an impact on the TSL. Participants in the supply chain have access to intelligent real-time tracking systems, the option of placing orders for containers and space on the ship through online service providers or issuing electronic shipping documents. The basis for starting work on the e-CMR electronic bill of lading was the Additional Protocol to the CMR Convention concerning the electronic bill of lading from 20.02.2008. The first transport using the e-CMR consignment took place on the 19 th of 2017 between the Spanish Huelva and the French city of Perpignan. The TransFollow application was used to handle the first transport using the e-CMR letter. The most important benefits of implementing an electronic bill of lading e-CMR can include: approx. 3-4-fold reduction of handling costs as well as transparency and identification of transport processes.

The purpose of the article is to present issues related to the CMR Convention and an international CMR consignment note and current work on the development of the e-CMR consignment note. In the first part of the article the CMR Convention and the principles of trading in the CMR letter were characterized. In the second part, the subject of the Fourth Industrial Revolution and works related to the implementation of the e-CMR electronic waybill were taken. The article was prepared using literature on the subject matter of the Convention and the CMR consignment note as well as internet sources describing the work on the e-CMR electronic consignment note. 


\section{Wprowadzenie}

Jednym z najważniejszych obszarów działań konwencji CMR (z fr. Convention relative au contrat de transport international de marchandises par route) regulującej zasady międzynarodowego przewozu rzeczy jest ujednolicenie listu przewozowego CMR. Jest on najważniejszym dokumentem w transporcie samochodowym. Stanowi potwierdzenie podjęcia i dostawy towaru. Jest wykorzystywany w celach rozliczeniowych pomiędzy stronami umowy transportu oraz celno-podatkowych. Jest wystawiany $\mathrm{w}$ formie papierowej w trzech jednobrzmiących egzemplarzach oraz dowolnej liczbie kopii.

Upowszechnienie się dostępu do internetu pozwoliło na rozwój narzędzi informatycznych, przyczyniając się do powstania czwartej rewolucji przemysłowej cechującej się cyfryzacją produkcji i usług. Rozwój technologii informatycznych pozwolił na rozpoczęcie prac nad elektronicznym listem przewozowym (e-CMR) dającym możliwość śledzenia przesyłki w czasie rzeczywistym, dostępu do danych statystycznych dotyczących przewozu oraz zmniejszającym istotnie koszty związane $\mathrm{z}$ obsługą dokumentacyjną.

Celem artykułu jest przedstawienie prac związanych z wdrożeniem e-CMR oraz możliwości jego zastosowania w praktyce gospodarczej. W pierwszej części artykułu przedstawiono kwestie dotyczące konwencji CMR oraz charakterystyka i zastosowanie listu CMR. W drugiej części podjęto tematykę czwartej rewolucji przemysłowej (Gospodarka 4.0) oraz jej wpływu na gospodarkę. Omówiono prace nad wdrożeniem e-CMR, uwzględniając szczegóły organizacji pierwszego transportu z wykorzystaniem elektronicznego listu przewozowego oraz korzyści płynące z tytułu wykorzystania e-CMR zarówno dla uczestników procesów transportowych, jak i otoczenia gospodarczego.

\section{Międzynarodowy list przewozowy CMR}

Podstawą regulującą przewóz ładunków w transporcie samochodowym jest konwencja CMR sporządzona w 1956 roku w Genewie (Białkowski, 2011, s. 262), podzielona na 8 tematycznych rozdziałów, które dotyczą:

- zakresu stosowania,

- osób, za które odpowiada przewoźnik,

- zawarcia i wykonania umowy przewozu,

- odpowiedzialności przewoźnika, 
- reklamacji i roszczeń,

- postanowień dotyczących przewozu wykonywanego przez kolejnych przewoźników,

- nieważności klauzul sprzecznych z konwencją,

- postanowień końcowych.

Konwencja CMR znajduje zastosowanie w przypadku zarobkowego przewozu rzeczy przy użyciu pojazdów członowych, naczep i przyczep. Obecnie sygnatariuszami konwencji CMR jest 55 państw (rysunek 1), w tym od 27 kwietnia 1962 roku Polska ${ }^{1}$. Konwencja CMR jest więc dokumentem o zasięgu międzykontynentalnym, regulującym w ujednolicony sposób umowę międzynarodowego przewozu drogowego towarów (Wesołowski, Ambrożuk, Dąbrowski, 2015, s. 17). Nie ma zastosowania w przypadku przewozów zwłok oraz ładunków stanowiących mienie przesiedlenia, a także przy przewozach dokonywanych na podstawie odrębnych międzynarodowych konwencji. Co istotne, aby przewóz mógł się odbywać zgodnie z regułami konwencji CMR, kraj nadania lub odbioru musi być stroną konwencji (Starkowski, Bieńczak, 2009, s. 45).

Podstawą konwencji CMR jest międzynarodowy list przewozowy CMR wydawany w trzech jednobrzmiących egzemplarzach (pierwszy dla nadawcy, drugi dla odbiorcy, natomiast trzeci dla przewoźnika) oraz dowolnej liczbie kopii. Zwyczajowo jest to jedna kopia, aczkolwiek w przypadku transportów do i z państw Europy Wschodniej często niezbędna jest większa liczba kopii (Perenc, Godlewski, 2000, s. 110). Poszczególne egzemplarze listu CMR winny być samokopiujące, aby wykluczyć rozbieżności w treści pomiędzy stronami listu (Wesołowski, 2013, s. 185). List CMR składa się z 24 ponumerowanych pól określających nadawcę, odbiorcę i miejsce przeznaczenia, a także charakterystykę towaru (nazwę, ilość, kubaturę, wagę, kod taryfy celnej), przewoźnika i dalszych przewoźników, instrukcje dostawcy oraz zastrzeżenia i uwagi związane z dostawą, jak również warunki płatności.

Pierwszy egzemplarz listu CMR, podpisany i opieczętowany w polu 22 przed nadawcę i w polu 23 przez przewoźnika, pozostaje w rękach nadawcy jako potwierdzenie załadunku i przyjęcia przesyłki przez przewoźnika. Drugi egzemplarz listu otrzymuje odbiorca w miejscu przeznaczenia, potwierdzając odbiór w polu 24,

${ }^{1}$ Państwa będące sygnatariuszami konwencji CMR: Albania, Armenia, Austria, Azerbejdżan, Białoruś, Belgia, Bośnia i Hercegowina, Bułgaria, Chorwacja, Cypr, Czechy, Dania, Estonia, Finlandia, Francja, Gruzja, Niemcy. Państwa będące sygnatariuszami konwencji CMR: Grecja, Węgry, Iran, Irlandia, Włochy, Izrael, Kazachstan, Kirgistan, Lotwa, Liban, Litwa, Luksemburg, Malta, Mongolia, Czarnogóra, Maroko, Holandia, Norwegia, Polska, Portugalia, Mołdawia, Rumunia, Rosja, Serbia, Słowacja, Słowenia, Hiszpania, Szwecja, Szwajcaria, Syria, Tadżykistan, Macedonia, Tunezja, Turcja, Turkmenistan, Ukraina, Wielka Brytania i Irlandia Północna, Uzbekistan. 
Rysunek 1. Państwa będące sygnatariuszami konwencji CMR

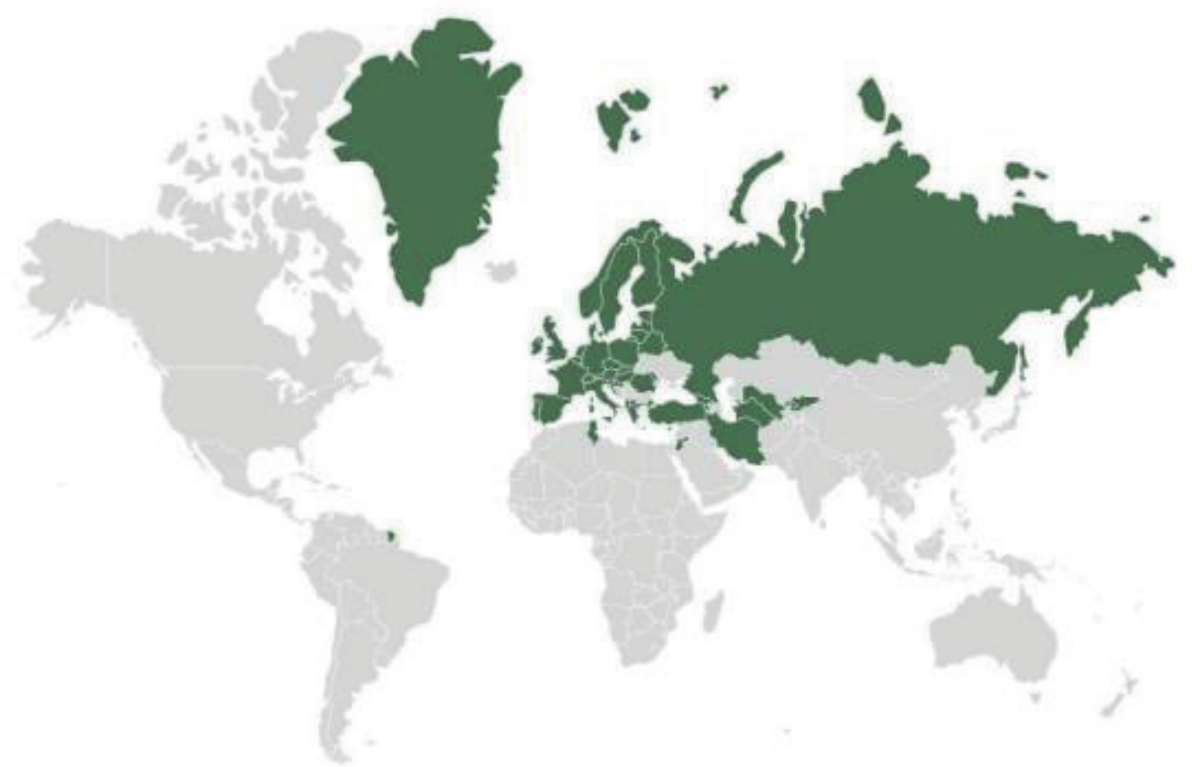

Źródło: http://www.smartmobilityworld.net/.

natomiast trzeci egzemplarz trafia do przewoźnika jako potwierdzenie wykonania przewozu. Kopie listu CMR są wykorzystywane w celach rozliczeniowych pomiędzy stronami zlecenia transportowego lub mogą być wymagane przez organy celno-podatkowe w przypadku przekraczania granicy oraz jako potwierdzenie realizacji procedur celnych.

List CMR zwyczajowo wystawiany jest przez przewoźnika w miejscu załadunku, nadawcę lub reprezentującego go spedytora. Należy zaznaczyć, że nadawcą może być zarówno przedsiębiorstwo dokonujące fizycznego załadunku na środek transportu, jak i podmiot zlokalizowany w innym miejscu, jedynie zlecający załadunek. List przewozowy CMR obecnie wystawiany jest $\mathrm{w}$ formie papierowej z wykorzystaniem wzoru opracowanego przez Międzynarodową Unię Transportu Drogowego (IRU) w 1976 roku (załącznik 1). W wielu przypadkach list CMR jest wzbogacony o logo nadawcy (listy robione na zamówienie) oraz posiada kolorowe strony (czerwona dla nadawcy, niebieska dla odbiorcy, zielona dla przewoźnika). Należy zaznaczyć, że konwencja CMR dość liberalnie odnosi się do faktu posiadania 
listu przewozowego przez przewoźnika, zaznaczając, że jego brak nie ma wpływu na ważność umowy przewozu pomiędzy stronami.

List przewozowy jako forma potwierdzająca załadunek i przyjęcie przesyłki realizuje następujące funkcje (Starkowski, Bieńczak, Zwierzycki, 2009, s. 45):

a) informacyjną - poprzez określenie miejsca nadania i przeznaczenia przesyłki, specyfikacji towarowej, a także instrukcji odnośnie do ewentualnej odprawy celnej i opłat list CMR spełnia funkcję informującą dla każdej ze stron zaangażowanych bezpośrednio (nadawca, odbiorca, przewoźnik) i pośrednio (urzędy kontroli i nadzoru procesu transportowego);

b) instrukcyjną - szczegółowe informacje zawarte w poszczególnych rubrykach listu CMR (miejsce przeznaczenia, odprawy celnej, nr zamówienia, faktury itp.) stanowią instrukcję dla przewoźnika/kierowcy odnośnie do niezbędnych do wykonania czynności);

c) legitymacyjną - zawarte w liście przewozowym informacje mogą służyć identyfikacji danej partii towarowej w miejscu odprawy celnej (nr OLG/ MRN) lub miejscu przeznaczenia (nr zamówienia, faktury, kontraktu itp.), co weryfikuje daną dostawę i pozwala na sprawne dokonanie czynności celnych i manipulacyjnych;

d) dowodową - jako dowód nadania, przyjęcia i dostarczenia określonej w liście przewozowym partii ładunkowej.

Przewoźnik jest zobowiązany do zweryfikowania informacji zawartych w liście przewozowym ze stanem faktycznym, a w przypadku zauważenia rozbieżności odnotowania ich w liście przewozowym (Garnowski, 2017, s. 33).

List i konwencja CMR stanowią zatem istotne narzędzia regulujące międzynarodowy przewóz rzeczy, zabezpieczając interesy wszystkich stron uczestniczących w przewozie.

\section{Zastosowanie elektronicznego listu przewozowego (e-CMR)}

Początek drugiej dekady XXI wieku to trwający do dziś czas intensywnej cyfryzacji gospodarki. Okres ten charakteryzuje się dużym naciskiem na automatyzację wytwarzania dóbr i usług oraz informatyzację przesyłania danych. Koncepcja związana z powyższym zjawiskiem została nazwana czwartą rewolucją przemysłową (Gospodarka 4.0 - Industrie 4.0). Termin Gospodarka 4.0 został po raz pierwszy użyty w 2011 roku na targach w Hanowerze i stał się określeniem dla globalnych przemian gospodarczych (https://www.vdi-nachrichten.com). Charakterystyczna dla Gospodarki 4.0 jest dynamizacja wykorzystania dostępnych narzędzi internetowych dla 
poprawy przesyłania danych, przejawiająca się między innymi poprzez integrację (Hermann, Pentek, Otto, 2015, s. 3):

a) społeczeństwa w mediach społecznościowych i biznesowych;

b) rzeczy i usług w inteligentnych sieciach transportowo-logistycznych;

c) danych poprzez transfer informacji ze standardowych, papierowych źródeł do zaawansowanych systemów pozwalających na podejmowanie decyzji $\mathrm{i}$ ich realizację w czasie rzeczywistym.

Postęp w dziedzinie informatyzacji gospodarki nie pozostał bez wpływu na branżę TSL. Uczestnicy łańcucha dostaw od lat mają dostęp do inteligentnych systemów śledzenia przesyłki w czasie rzeczywistym, możliwość składania zamówienia na kontenery i miejsce na statku poprzez internetowe serwisy armatorskie czy wystawiania elektronicznych dokumentów przewozowych oraz obsługi ładunków w portach z wykorzystaniem systemów WMS, bez konieczności przygotowywania papierowej dokumentacji.

Scharakteryzowany w pierwszej części artykułu międzynarodowy list przewozowy CMR jest najważniejszym dokumentem w transporcie samochodowym. Pomimo iż w konkurencyjnych gałęziach transportu digitalizacja dokumentacji transportowej stała się faktem (elektroniczny list przewozowy w przewozach kolejowych, SeaWaybill w transporcie morskim), list CMR, mimo potrzeb ze strony uczestników łańcucha dostaw, przez wiele lat był wystawiany jedynie w formie papierowej.

Prace nad wdrożeniem e-CMR doprowadziły do zorganizowania pierwszego międzynarodowego przewozu z wykorzystaniem elektronicznej dokumentacji. Podstawą prawną przewozu był protokół dodatkowy do konwencji CMR dotyczący elektronicznego listu przewozowego z 20 lutego 2008 roku. Po jego ratyfikacji przez Litwę, Łotwę, Szwajcarię, Finlandię i Bułgarię wszedł w życie 5 czerwca 2011 roku. Protokół jest podstawą dla e-commerce w międzynarodowym transporcie drogowym. Zgodnie z protokołem międzynarodowy list przewozowy CMR może zostać wystawiony $\mathrm{w}$ formie elektronicznej z zachowaniem zasad bezpieczeństwa i stanowi ekwiwalent dla papierowego dokumentu oraz posiada taką samą moc prawną. Aby e-CMR mógł zostać uznany za pełnoprawną dokumentację transportową, wymaga się, aby został opatrzony wiarygodnym podpisem elektronicznym (wymogi dla podpisu elektronicznego są tożsame z wymogami ustawy o podpisie elektronicznym z 18 września 2011 roku). W liście przewozowym wystawionym w formie elektronicznej powinna być możliwość ponadto wprowadzenia takich samych informacji jak w tradycyjnym, papierowym dokumencie. Procedura elektronicznego listu przewozowego powinna zapewniać integralność i niezmienność danych w nim zawartych, z wyjątkiem zmian, które powstają w normalnym toku transferu danych 
pomiędzy stronami (Wesołowski, 2013, s. 188). Protokół z 2008 roku reguluje między innymi (Protokół, 2011):

a) zakres stosowania e-CMR;

b) uwierzytelnianie dokumentu;

c) warunki ustanowienia e-CMR;

d) wdrożenie e-CMR;

e) dokumenty uzupełniające list przewozowy;

f) warunki ratyfikacji protokołu.

Pierwszy transport z wykorzystaniem e-CMR odbył się 19 stycznia 2017 roku pomiędzy hiszpańską Huelvą a francuskim miastem Perpignan. Organizatorem przewozu była Międzynarodowa Unia Transportu Drogowego (International Road Transport Union - IRU) przy współpracy z hiszpańskim Związkiem Transportu Międzynarodowego (Asociacion Del Transporte Internacional Por Carretera ASTIC) oraz francuską Krajową Federacją Transportu Drogowego (Fédération Nationale des Transports Routiers - FNTR). Przedmiotem przewozu na liczącej 1300 km trasie były pomarańcze. Do obsługi pierwszego transportu z wykorzystaniem e-CMR posłużyła aplikacja TransFollow (Transfollow.org). Przy przewozie zostały wykorzystane: tablet Lenovo oraz telefon Samsung J3, aby potwierdzić funkcjonalność systemu na urządzeniach opartych na oprogramowaniu Android. Realizacja pierwszego transportu z wykorzystanie e-CMR przebiegła bez zastrzeżeń, co pokazało, że ta forma dokumentowania przewozu jest zarówno prosta, jak i funkcjonalna. Obecnie trwają testy wdrożeniowe dla zastosowania e-CMR we krajach Beneluksu - Belgii, Holandii i Luksemburgu (Testy e-CMR w krajach Beneluksu).

Wykorzystanie e-CMR niesie ze sobą wiele udogodnień zarówno dla nadawcy, odbiorcy, przewoźnika, jak i otoczenia logistycznego obsługującego transport. Podczas konferencji Smart Mobility World w Turynie (10 października 2017 r.) Międzynarodowa Unia Transportu Drogowego wskazała listę korzyści dla wszystkich zaangażowanych podmiotów, do których należą:

a) około 3-4-krotne obniżenie kosztów manipulacyjnych, co przejawia się poprzez:

- usprawnienie administracji (mniej danych do wprowadzenia, mniejsze wykorzystanie papieru/skanera/faksu, brak konieczności archiwizacji papierowej dokumentacji),

- usprawnienie fakturowania, brak konieczności oczekiwania na oryginały dokumentów, które są podstawą do wystawienia faktury,

- zmniejszenie rozbieżności pomiędzy towarem załadowanym, a dostarczonym;

b) przejrzystość i lepsza identyfikacja, co przejawia się poprzez: 
- dokładność danych,

- monitorowanie przesyłki w czasie rzeczywistym,

- otrzymywanie potwierdzenia załadunku i dostawy bez konieczności kontroli z załadowcą/odbiorcą/przewoźnikiem.

Wystawienie elektronicznej dokumentacji przewozowej wiąże się także z kosztami dla przedsiębiorstwa, jednak są one zdecydowanie niższe niż w przypadku papierowej dokumentacji. O porównanie tych kosztów postarała się firma TransFollow (rysunek 2), która na swojej stronie internetowej daje możliwość kalkulacji przybliżonych opłat związanych $\mathrm{z}$ wystawieniem dokumentów przewozowych w formie papierowej i elektronicznej.

Rysunek 2. Porównanie kosztów wystawienia papierowej i elektronicznej dokumentacji przewozowej

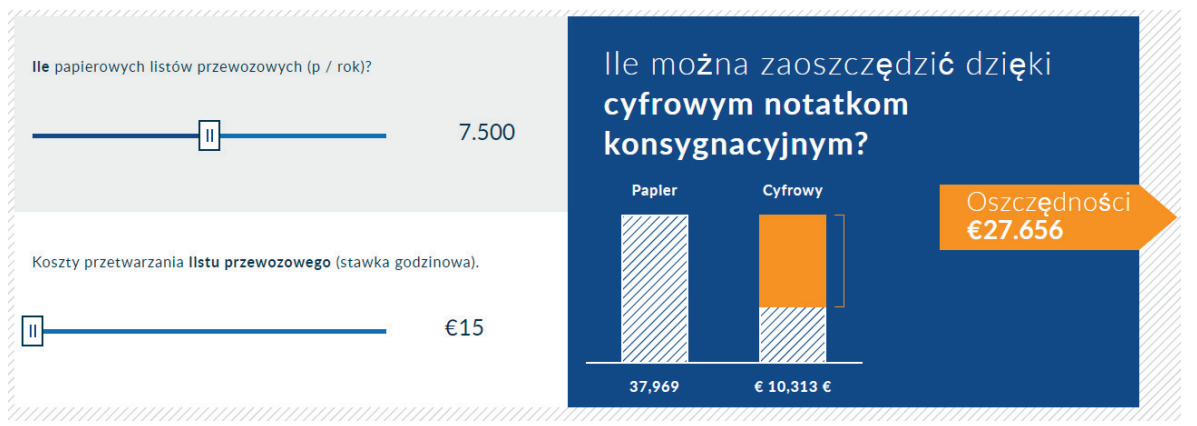

Źródło: https://www.transfollow.org/en.

Analizując powyższe, jeżeli przyjąć liczbę wystawionych papierowych listów przewozowych na poziomie 7500 sztuk w skali roku (przy 251 dniach roboczych w 2018 r. daje to niecałe 30 listów przewozowych dziennie) oraz koszt przetwarzania papierowej dokumentacji na poziomie 15 euro za godzinę, oznacza to oszczędności w skali roku na poziomie 27656 euro (bez uwzględniania kosztów związanych z integracją systemu TransFollow).

Ponadto wdrożenie e-CMR niesie ze sobą korzyści dla otoczenia logistycznego w postaci (http://www.smartmobilityworld.net):

a) integracji z systemami celnymi pozwalającej na kontrolę aktualnego statusu celnego przewożonych towarów oraz dokonywanie zgłoszeń w czasie rzeczywistym;

b) współpracy z innymi usługami branżowymi, jak zarządzanie flotą pojazdów, serwis; 
c) zwiększenia bezpieczeństwa na drodze poprzez automatyczne połączenia alarmowe dla ciężarówek;

d) zwiększenia ogólnej efektywności przewozów, co ma przełożenie na większą ekonomiczną konkurencyjność branży transportowej oraz państw będących sygnatariuszami protokołu dodatkowego do konwencji CMR

Głównym celem wprowadzenia e-CMR jest znaczna redukcja kosztów. Obecnie list CMR jest drukowany w co najmniej 4 kopiach, dodatkowe koszty związane są z jego przesłaniem oraz archiwizacją. Ponadto wystawienie listu jest czasochłonne i często wymaga zaangażowania spedytora do bezpośredniego dostarczenia dokumentu do kierowcy. Wdrożenie e-CMR pozwoli na minimalizację wykorzystania papieru oraz usprawni wymianę dokumentacji pomiędzy stronami.

\section{Podsumowanie}

Branża transportowa przez wiele lat posługiwała się dokumentami wystawianymi w formie papierowej. Rozwój narzędzi internetowych pozwolił na digitalizację dokumentacji w transporcie kolejowym i morskim, a także na rozwój tego aspektu w transporcie samochodowym. Sporządzony w 2008 roku protokół dodatkowy do konwencji CMR dał możliwość rozpoczęcia prac nad e-CMR.

Pierwszy przewóz z wykorzystaniem e-CMR odbył się pomiędzy Hiszpanią a Francją. Obecnie trwają testy nad wdrożeniem e-CMR w krajach Beneluksu.

Szacuje się, że wykorzystanie elektronicznego listu przewozowego pozwoli na oszczędności w postaci 3-4-krotnego obniżenia kosztów manipulacyjnych (zmniejszenie wykorzystania papieru, ograniczenie archiwizacji dokumentów papierowych) oraz poprawienia przejrzystości samego procesu transportowego (monitorowanie przesyłki w czasie rzeczywistym, dokładność danych, informacja o przebiegu dostaw).

Mając na uwadze zapoczątkowaną przez dynamiczny rozwój internetu i trwającą obecnie czwartą rewolucję przemysłową, można domniemywać, że dalszy rozwój dokumentacji przewozowej będzie przebiegał w kierunku jej digitalizacji oraz transferu danych do zintegrowanych systemów, przetwarzanych w czasie rzeczywistym. 


\section{Literatura}

Białkowski, M. (2011). Umowa o międzynarodowym przewozie drogowym towarów. Problemy Transportu i Logistyki, 14, 261-277.

First Ever Border Crossing to Use e-CMR Electronic Consignment Note. Pobrane z: https:// www.transfollow.org (10.08.2018).

Garnowski, K. (2017). Funkcja dowodowa listu przewozowego w lądowym transporcie towarów. Problemy Transportu i Logistyki, 4 (40), 31-40.

Hermann, M., Pentek, T., Otto, B. (2015). Design Principles for Industrie 4.0 Scenarios: A Literature Review. Dortmund: Technische Universität.

Industrie 4.0: Mitdem Internet der Dinge auf dem Wegzur 4. industriellen Revolution. Pobrane z: https://www.vdi-nachrichten.com (10.08.2018).

Konwencja o umowie międzynarodowego przewozu drogowego towarów (CMR) sporządzona w Genewie 19.05.1956. Dz.U. 1962, nr 49, poz. 238, sprost. Dz.U 1995, nr 69, poz. 352.

Perenc, J., Godlewski, J. (red.) (2000). Międzynarodowe przewozy towarowe. Warszawa: Polskie Wydawnictwo Transportowe.

Protokół dodatkowy do konwencji dotyczącej Międzynarodowego przewozu rzeczy CMR z 5.06.2011 dotyczący elektronicznego listu przewozowego.

Smart Mobility World. Pobrane z: http://www.smartmobilityworld.net/ (26.08.2018).

Starkowski, D., Bieńczak, K., Zwierzycki, W. (2009). Samochodowy transport krajowy i międzynarodowy. Kompendium wiedzy praktycznej. Przepisy prawne. T. 2. Poznań: Systherm D. Gazińska.

Testy e-CMR w krajach Beneluksu. Pobrane z: https://trans.info/pl (11.08.2018).

Wesołowski, K. (2013). Umowa międzynarodowego przewozu drogowego towarów na podstawie CMR. Warszawa: Wolters Kluwer.

Wesołowski, K., Ambrożuk, D., Dąbrowski, D. (2015). Konwencja o umowie międzynarodowego przewozu drogowego towarów (CMR). Komentarz. Warszawa: Wolters Kluwer. 
Załącznik 1 - międzynarodowy list przewozowy CMR

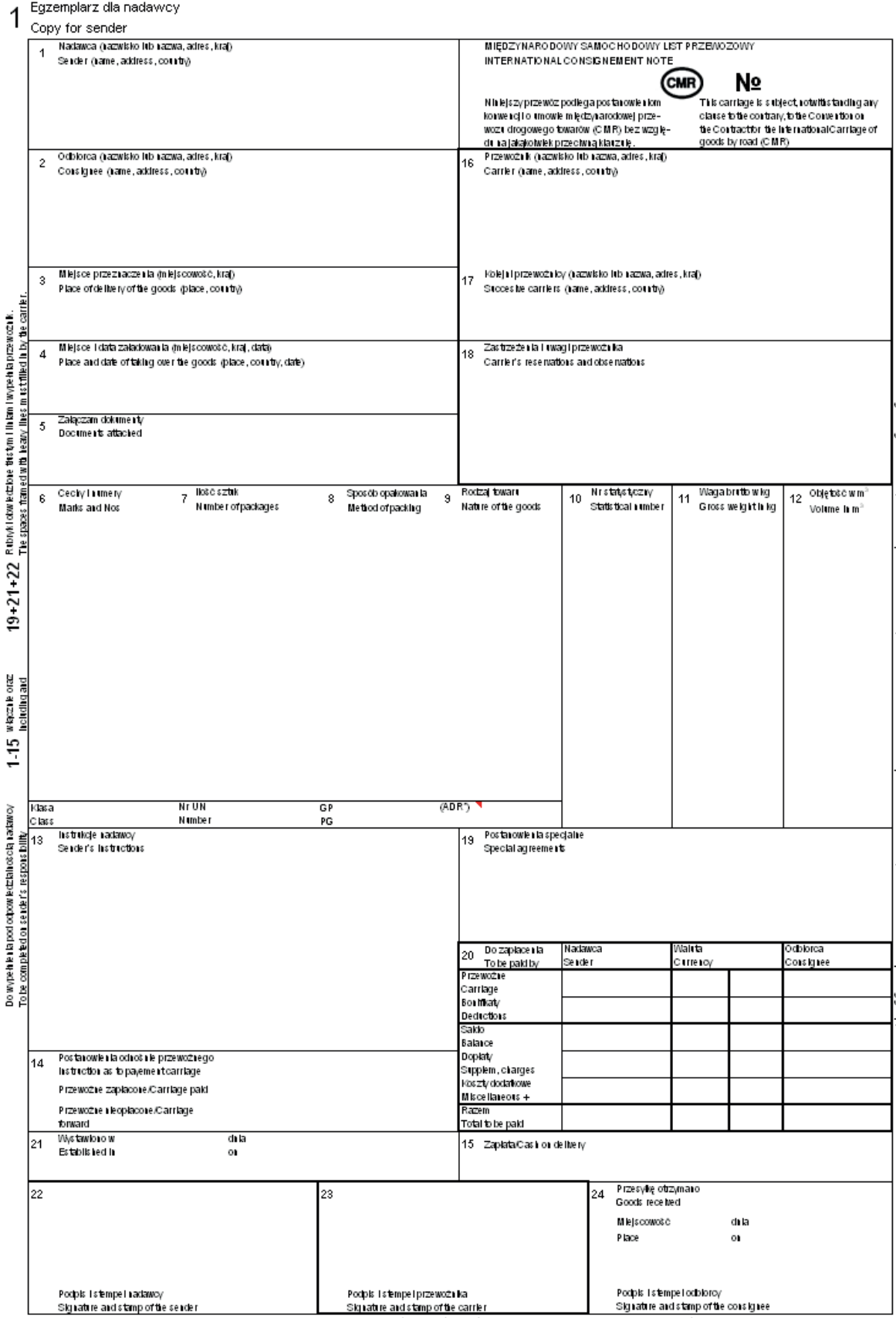

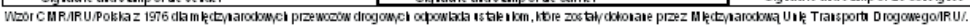

(1) wuw.signform.pl Sp. z o.o., producent aktywnych formularry, e-mail: biuro @signform.pl 